\title{
Perception, Identity and Meaning in the Social and Ritual Construction of Landscape: The Lihue Calel Hills, La Pampa, Argentina
}

\author{
Percepción, Identidad y Sentido en la Construcción Social y Ritual \\ del Paisaje: las Sierras de Lihue Calel, La Pampa, Argentina
}

Rafael P. Curtoni i and Mónica A. Berón ${ }^{\mathrm{II}}$

\begin{abstract}
This paper discusses how the social construction of landscape and the sense of identity and territoriality can emerge in relation to a ritual space. Through the analysis of monumental constructions or arrangements of rocks, its topographical connection and the location of cave paintings and cemeteries, a ritualized landscape may be defined. The archaeological information of the Sierras Lihue Calel is employed for this. This area is located in the western sector of the pampean region of Argentina.
\end{abstract}

Key Words: Social Landscape, Ritual Space, Identity, Territory, Pampean Region.

\section{RESUMEN}

En este trabajo se discute cómo la construcción social del paisaje y el sentido de identidad y territorialidad pueden emerger en relación a un espacio ritual. A través del análisis de construcciones monumentales o arreglos de rocas, su vinculación topográfica y la localización de pinturas rupestres y cementerios, se puede delinear un paisaje ritualizado. Para ello se utiliza información arqueológica de las Sierras de Lihué Calel. Esta área está ubicada en el sector oeste de la región pampeana argentina.

Palabras Claves: Paisaje Social, Espacio Ritual, Identidad, Territorio, Región Pampeana.

Conicet, Facultad de Ciencias Sociales, Universidad Nacional del Centro de la provincia de Buenos Aires, Avda. del Valle 5737 (7400) Olavarría, Buenos Aires. Correo-e: rcurtoni@soc.unicen.edu.ar

ii Conicet, UBA, UNICEN, Museo Etnográfico "Juan B. Ambrosetti", Moreno 350, Ciudad Autónoma de Buenos Aires. Correo-e: monberon@retina.ar Recibido: Octubre 2010 Aceptado: Julio 2011 


\section{INTRODUCTION}

Through time the spatial occupation by human groups and the continuous familiarity with their environment can strengthen feelings and perceptions, along with senses of acceptance, belonging and ownership to a place (Tuan 1977). The reactions of the perceiver can be related to feelings of refusal or unbelonging toward certain places and landscapes. In this manner, a specific place can promote different reactions on persons, with reference to their own values, dynamics and meanings (Tilley 1994). Repetition of these conceptualizations though time and the consequent forms of these approximations/actions generate spatial routines and consciousness of habitual incorporation of special places in the landscape (Gosden 1994, Taçon et al. 1997). In this sense, the socialization of the landscape through the process of monumentalizing and objectifying cultural practices can generate hierarchical orderings and/or organization of space into "places". These are conceptualized in a process of remembering and forgetting, or "memory-work", in which meanings are selected and linked by the accumulation of different feelings over a life time (Shields 1991, Küchler 1993). Likewise, the intensity and quality of the experiences are perceived by their own histories and associated values (Hernando 1999, Roe and Taki 1999). Thus, a location where the dead are formally placed through time can be derived in a sacred space, imposing subsequent actions for people and the ritual involved. In this way, the cultural landscape emerges, it is dynamic and contains diverse physical and ideological characteristics from which meanings of ownership, identity, and even conflicting perceptions can be promoted (Tuan 1977). The objective of this paper is to discuss the process by which, around a sacred space, groups of hunter-gatherers build a cultural landscape whose differential ordering is a reflection of the accumulation of actions, group meanings, and individual senses through time. To discuss this theme, archaeological information from the Lihué Calel hills, of the western sector of the Pampas region, Argentina (Figure 1) is utilized, that combines the location of rock paintings, monumental architecture, and a pre-Hispanic cemetery related to cultural and topographical characteristics of the landscape.

The majority of the cultural manifestations analyzed here are concentrated on a portion of a previously surveyed landscape, which covers the south sector of the Lihué Calel hills, particularly two stream ("quebradas") or narrow valleys called Valley of Las Pinturas and Valley of Namuncurá. These valleys contain the majority of the rock paintings identified in the area; a series of stone structures of diverse morphology, size 
and functionality; different archaeological sites and at the end of one of the valleys a multiply used pre-Hispanic cemetery spanning some 700 years (Berón 2004).

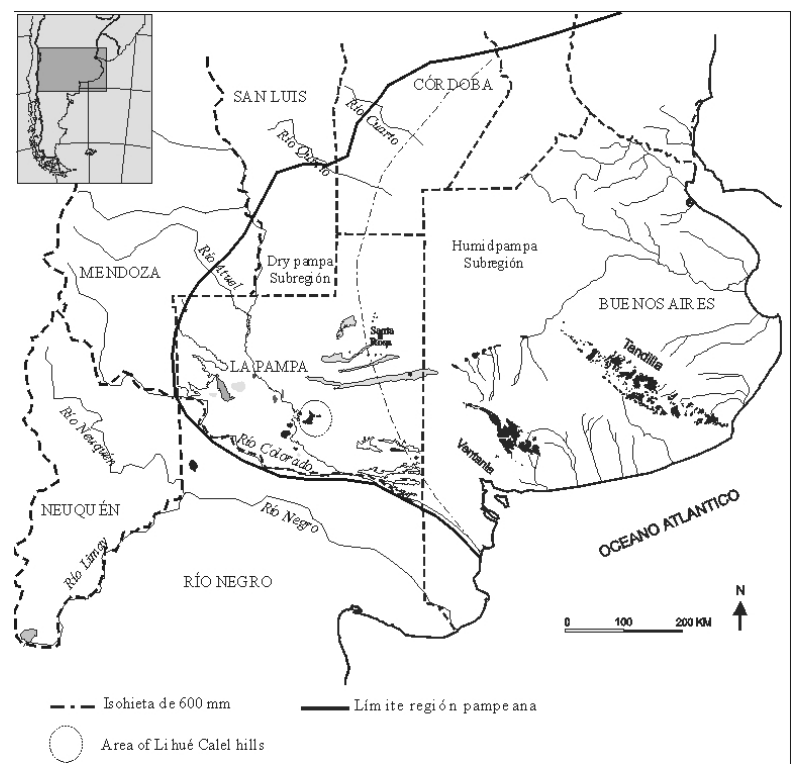

Figure 1: Location map of the Lihué Calel area.

Figura 1: Mapa con ubicación del área de Libué Calel

\section{Archaeology And landscape}

In previous decades there has been a noticeable increase in the utilization of the landscape concept in archaeological research from diverse regions of the world (Gosden 1989, Bradley 1991, Rossignol and Wandsnider 1992, Bender 1993, Tilley 1994, Hirsch 1995, Criado 1999, Muir 1999, Ucko and Layton 1999). In general, different methodological and theoretical approximations were developed relating to "Landscape Archeology". On the one hand, there are those that prioritize an empirical approach and emphasize the recognition of the physical characteristics which have modified the environment. Established among these orientations are Spatial Archeology and Cultural Ecology, which pay special attention to settlement patterns and the constant adaptation of man to the surroundings (Roberts 1987, see McGlade 1995). On the other hand, there are those that consider landscape regarding phenomenological and symbolical point of 
views, basing the interpretations on subjective experiences and through the recognition of sign systems. Among these approaches are the hermeneutic and phenomenological studies, as well as some variants of generic studies called Social Landscapes (Thomas 1993, Tilley 1994, Kirk 1997, Bender 1998). These trends can be considered as extreme positions, covering from the empirical and positivist positions to the radical idealism-humanistic paradigms. Classically, this division has been simplified in the archaeological discussion as to the dichotomy of the processual-postprocessual approaches. It is not the objective of this work to extend this discussion, nor to undertake the complexity and quantity of perspectives developed in relation to landscape archeology, for that reason the works of synthesis and anthologies are mentioned here (Rossignol and Wandsnider 1992, Bender 1993, Carmichael et al. 1994, Mitchell 1994, Hirsch and O' Hanlon 1995, Ashmore and Knap 1999, Muir 1999, Ucko and Layton 1999, Anschuetz et al. 2001, David and Thomas 2008, Nash and Children 2008, among others).

In the anthropological sciences and in archeology the concept of 'landscape' has been acknowledged in different ways, as a portion of terrain within which people dwell, as an aggregate of material and cultural traces, or as the topographical characteristics and land forms of a given region (Thomas 2001). Landscape can also be recognized as an object, an experience or as the cultural construction process, an outcome of multiple political, historical, and ideological factors that have produced a particular way of conceptualizing and operating on it (Hirsch 1995). In a similar vein, landscape was characterized as a cultural product created by the objectification of social action so much material as symbolic (Criado 1999). The landscape is the medium and consequence of social practices, it is dynamic and charged with symbolism, 'created' by the individuals through memories and evocations of events and places, formed by a range of locales and sites of diverse importance, and acknowledges as much the past as the present (Ingold 1993, Tilley 1994, Morphy 1995). In this sense, the idea of landscape has also been focused considering a multidisciplinary archaeological project and allowing for a multivocal ways of conceptualizing both ancient and modern stories about space (Bender et al. 2007). On the other hand, some researchers have concentrated on the importance of unaltered features of the landscape exploring why natural places assumed a sacred character in the past (Bradley 2002). Lastly landscape can be regarded as a set of relationships between people and places implying an ongoing process in which multiples significances can emerge as result of the social practices of building, dwelling and being in the world. 
In this paper we discusses the landscape socialization process through the 'monumentality', 'objectiveness' and the carrying out of cultural practices related with the worship of the deceased. Monuments and the spatial socialization practices acts as mnemonic tools and references of actions and identities (Taçon 1994, Roe and Taki 1999). The time and energy invested in their construction demands organization, planning and significance. This cultural practice of materialization is referring to particular social actors and in a sense contributes to strengthen identity. The prolongation in time/ space as well as the conceptualizations that surround the monument, such as any associated actions, promotes its identification in the place/landscape as something special, sacred, or different (Bradley 1991, Taçon 1994, Morphy 1995). From this, in a sacred space the significance of approximation to it and the ceremonial movements, are pre-established with the arrangements and combinations of topographic features with monuments, implying also a different temporality of the mundane action (Bradley 1991, Hubert 1994, Tilley 1996).

\section{THE ARCHAEOLOGICAL LANDSCAPE OF LIHUÉ CALEL}

From a physiographic point of view, the area of Lihué Calel forms part of the micro region called Southern Hills of the Pampas (Serranías Pampeanas Meridionales). The area covers nearly all the Lihué Calel County, the southern portion of the Utracán County and the eastern portion of the Curacó County, in the south of the province of La Pampa (Berón 2004, Berón et al. 2007). The Lihué Calel hills represent one of the most prominent geographical characteristics of the province by its great extension and strong relief, located between the meridians $64^{\circ} 45^{\prime}$ to $66^{\circ} \mathrm{LW}$ and the parallels $37^{\circ} 30^{\prime}$ to $38^{\circ} 30^{\prime}$ LS. The maximum height of the Lihué Calel hills is $589 \mathrm{~m}$. The relief is composed of hills with conical forms surrounded by flat and staggered "piedemontes" (Figure 2). At the western end of these geographical formations are low lying areas and saltpeter beds (Cano 1980). 


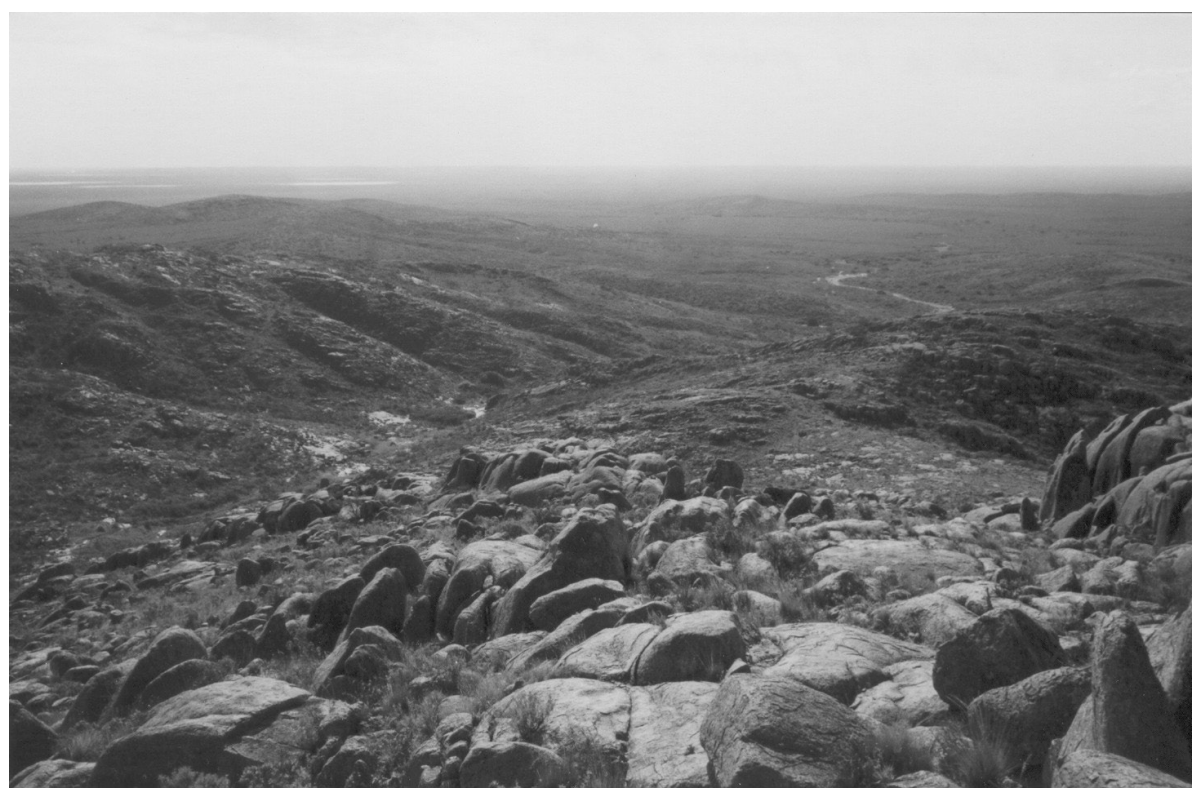

Figure 2: Panoramic view of Lihué Calel hills.

Figura 2: Visión panorámica de las Sierras de Libué Calel.

A large part of the area is protected under the jurisdiction of the National Parks Administration (APN). The Lihué Calel National Park (PNLC) has an extension of almost 10,000 ha. Most of the park is located in the hills, approximately $15 \mathrm{~km}$ long by $7 \mathrm{~km}$ wide, with different valleys in their interior which contain natural springs and courses of water. It is an area highly concentrated and abundant with resources. Its geomorphology enables the establishment of a humid and more favorable microclimate than that of the adjacent areas, thus being constituted as a geomorphologic and biological land mass. The hilly relief contributes to the detainment of water during dry and moderate summer temperatures.

From an archaeological stand point the initial investigations of the Lihué Calel Park were related to sporadic approaches in which for the first time descriptions of the rock art were presented (Schazky 1954) as well descriptions of diverse types of archaeological sites (Zetti and Casamiquela 1967). In 1975, Gradin contributed to new information on the diverse rock paintings from sites within the province of La Pampa, of which some of them where from Lihué Calel. Gradin has also made temporary interpretations of their motives, assigning them to late chronological related styles (Gradin 1975). Recently in 1993 investigations in the Park using systematic and regional surveys were undertaken, this time trying to integrate the different 
archaeological records (Molinari 1994, Berón 1997, see summary in Berón and Curtoni 2002, Berón et al. 2002). As a result of these successful investigations, 48 archaeological sites were recorded inside the limits of the PNLC, and two outside of the protected area. Among the sites discovered inside the National Park, 14 contain rock art, 11 are recognized as historical sites, 17 pre-Hispanic sites, and six are represented by stone structures. Outside of the Park limits there is a pre-Hispanic and historic quarry site (Las Minas de Cobre), and an additional pre-Hispanic site (Los Ranqueles). Keeping in mind the results of earlier surveys and shovel tests, from 1998 to 2006, excavations were carried out at the site "Chenque 1", located in the southwest sector of the Park (for a synthesis see Berón et al. 2000, 2002). There were also other sites found in this sector of the Park with cultural manifestations of interest such as the site La Casona, as well as constructions or arrangements of superficial rocks (denominated Structures 1 and 2), rock paintings, and the site El Dolmen (also with rock paintings).

\section{Sacred space and mortuary rituals: the Chenque 1 site}

The site Chenque 1 is a multiple funeral structure located at the summit of a low hill placed to the north of the Valley of Las Pinturas. The summit is an open space with abundant sedimentary accumulation. The site is composed by a large superficial structure of rocks; approximately circulate in form, of cultural origin, and with an extension of $16.70 \mathrm{~m}$ north to south and $12.60 \mathrm{~m}$ east to west $\left(210.42 \mathrm{~m}^{2}\right)$. Within this structure there exist small and circular superficial and buried structures, which would indicate the burial of one or various individuals. Thus far, an area of $49 \mathrm{~m}^{2}$ has been excavated, which constitutes a sample of 23 percent of the surface demarcated superficially.

The archaeological record exhibits high variability, such as in burial modalities, and the character of the buried individuals (children and adults of different ages and of both sexes). There was no post-Hispanic remains recovered. Various cultural accessories have been recovered (necklaces of diverse material, metallic ornaments, shells and lithic tools). The minimum number of individuals buried is 216 , although this is a provisional number given that not all of the pertinent adjustments in relation to the remains recovered in the last three excavations have been included (March, May and December of 2006). This permits us to estimate that various hundreds of individuals that have been buried at the site (Berón et al. 2007, Luna 2008). 
The combination of multiple factors, like the increase in population pressure, a tendency toward the reduction in mobility, the growth of social networks and spatial interactions as much as the intensification in the production of ornaments and symbolic expressions such as rock-art or stone arrangements as markers, could contribute to the generation of a sacredly notion of a place. The burying of the dead could serve to establish links, to guarantee and to legitimize the social relations among groups, to consolidate determined political strategies, and to legitimize networks of preexisting social relations. The spatial location of bone concentrations (remains removed of old burial) towards the interior burial circle could be associated to these behaviors. The fact that the anthropic rearrangements are located inside the same site, and they have not been arranged outside the sites limits, implies the acknowledgement of some type of relation and/or respect towards the buried on the part of those whom carried out the removals. According to the spatial analysis, such as the position of the burials (circulate centrifuge) and the concentrations (centripetal), support the criterion of delimitation, but also suggest a sense of sacredness. That is to say, the Chenque 1 site is located in a noticeable topography, but is also a cultural type mound formation built by means of new burial deposits, the planned removal of previous burials, and the removal and addition of sediments (Luna et al. 2004).

In the case of the Chenque 1 site, the generation of this formal burial area could have contributed to reinforce social inclusion among different groups, motivated not only by economic questions, but also by circumstances of distribution, control and exchange of people, goods, information, ritual knowledge, and power. In a situation characterized by a semi-desert type environment, the maintenance of social relations guarantees the access to resources and alternative know-how that permit to diminish the inherent risks in the unpredictability of these zones (Berón 2004).

Buikstra and Charles (1999) interpreted that the cemeteries located on the top of a hillock represent monuments to the dead, evidence of homage to the ancestors, located above the community in double liminal zones between the land and the sky, and the valley and the high lands, from which the ancestors could influence the world of the living. Considering this we can affirm that the Chenque 1 site is a social funeral structure, and that it was ritually built. Having this in mind, we conducted a systematic evaluation of cultural and biological variables. Upon considering the chronologic tendencies of the cultural practices related to death during the late Holocene in the province of La Pampa, patterns were observed in relation to the dynamics of the populations in the area, and to the models of pre-Hispanic 
colonization on a macro-regional scale (Borrero, 1989/90, Barrientos and Pérez 2002). From this, the crossing variables such as sex, stature, modality of the burial, cranial deformation and chronology of the bio-archaeological record of the last 4500 years in the south-central district of La Pampa, seems to reflect the presence of two different populations in the area (P1 and P2), although their range of coexistence only represents the last part of this period, and they come together the consecration of the same space for the dead in the last 1000 years (i.e. in the Lihué Calel cemetery) (Berón 2007a). Beyond the amplitude of scales that indicate marked interaction, these populations maintained strong ties with determined points of the landscape that were recognized as private or referential, and that responded, perhaps evidently in a ritual timetable, to developed activities of aggregation, among these to give final destiny to their ancestors (Berón 2007b). Time trends analyzed from the obtaining of more than 20 results of $14 \mathrm{C}$ Radiocarbon analyses of different structures of burial in the site, indicate that it was used almost with continuity between 1050 and 320 years $\mathrm{AP}^{1}$. However there is a hiatus of use of the cemetery of ca. 300 years (between 700 and 435 years AP) that temporarily matches with paleoclimate record of an episode of severe drought (Stine 1994). This fact could correlate with a withdrawal from the territory by people who used this cemetery, perhaps moving to areas adjacent to permanent water resources, in which there have been recorded multiple burials in sites such as Paso Alsina and La Petrona, next to the Colorado River and Laguna de los Chilenos 1, whose chronologies partially cover the hiatus in the Chenque I (500-450 years AP, 500-300 years AP and $476 \pm 80$ years AP respectively) (Barrientos et al. 1997, Martinez and Figuerero Torres 2000, Martínez et al. 2006). To sum up, rituals, cosmological and climatic circumstances would have influenced the successive events of burial and/or transfer of the dead to the cemetery, as is also indicated by various historical chronicles for the region.

\section{The "sacredness" of space}

The most recent archaeological investigations have been concentrated in the southwest sector of the Lihué Calel National Park. In this sector and in a space of $3 \mathrm{~km}$ long (north to south) by $2 \mathrm{~km}$ wide, which constitutes the Valley of Las Pinturas, different topographical characteristics, monuments and/or cultural markers and social practices combined mutually to generate a social and lived space. The cemetery or the Chenque 1 site is located in the western section of the Park and is related and integrated into a wider space. The setting of the cemetery toward the west, where the sun falls, could be 
related to a concealed symbolic of the dead, with a non domestic and non routine space (Tilley 1994).

Likewise, as we mentioned before, the Chenque site is situated on a small hill that is located at the extreme south of the north valley and at the beginnings of an open zone that is directed toward the Valley of Las Pinturas. This valley contains a traveled tourist path related with permanent spring water, streams, and at least three rock art locations: the Alero de las Pinturas site in the center of the valley, the Dolmen site in extreme south (whose designs are described and interpreted later), and a rock wall with isolated designs in a small lateral open. In front of the Chenque site, some 500 meters to the east and on the peak of a high hill, a semicircular structure was built of stones with a rectangular rock in its center (Figure 3). This site has an approximate extension of $9 \mathrm{mx} 7 \mathrm{~m}$ in its exterior circle, the central rock being $2.10 \mathrm{~m} \mathrm{x} 1.10 \mathrm{~m}$ and $0.53 \mathrm{~m}$ in height. This structure (E1) is found aligned to the east/west line with the Chenque site and is also arranged along a north-south line with another rectangular structure located some 3 $\mathrm{km}$ to the south (E2). The southern structure (E2) is situated at the end of a narrow stream ("quebrada") or at the beginning of the south valley and is related along the east-west line with the site "El Dolmen", which contains rock paintings (Figure 4). The north-south alignment between the E1 and E2 has been well placed, to such extent that even a slight movement of one meter in any direction would hinder the viewing, given that the visual line is constrained by the edges of the sierras and surrounding hills (Figure 5). 


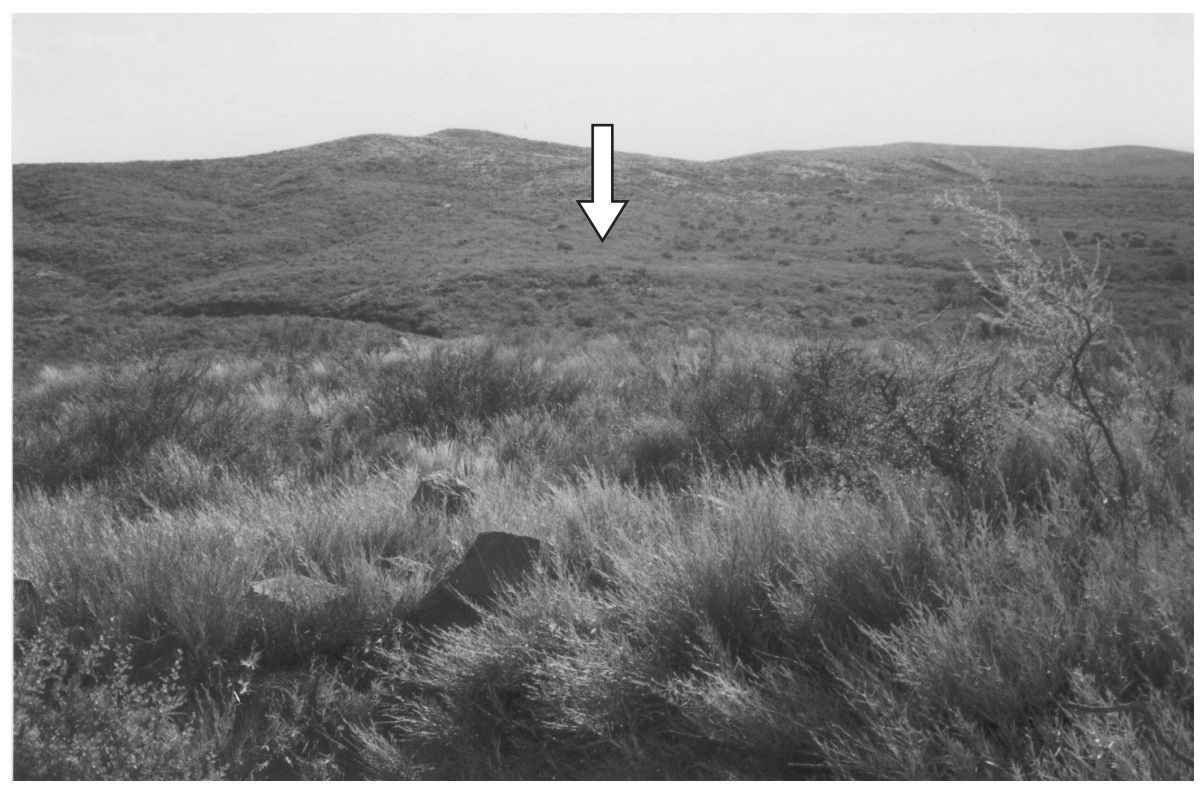

Figure 3: View of the structure one (E 1) and the "chenque" in the far end (at the arrow's point). Figura 3: Vista de la Estructura uno (E1) y del "chenque" al fondo (donde señala la flecha).

The rock paintings at the El Dolmen site were registered by Gradin in the 1970s (Gradin 1975) and although nowadays they are quite deteriorated, one of the composed motives is still observable and is of interest in this work. It is a composition of concentric circles connected by a straight line with two conflicting triangles. The El Dolmen site is located in the extreme south of a narrow stream ("quebrada") that leads towards the interior of the Valley of Las Pinturas, where the Alero de las Pinturas site is situated, and where the greater quantity of rock paintings in the Park are concentrated. It is proposed, at a speculative level, that the motive of the Dolmen site could be marking the orientation of a path which leads to the other paintings and to the Chenque site. The conflicting triangles could be to symbolize the respective valleys that exist to the north and south, and the concentric circles may signify the source of water or spring that exists there. These exploratory ideas try to represent and approximate to the complex intertwining of dwelling, living and acting on landscape throughout time. 


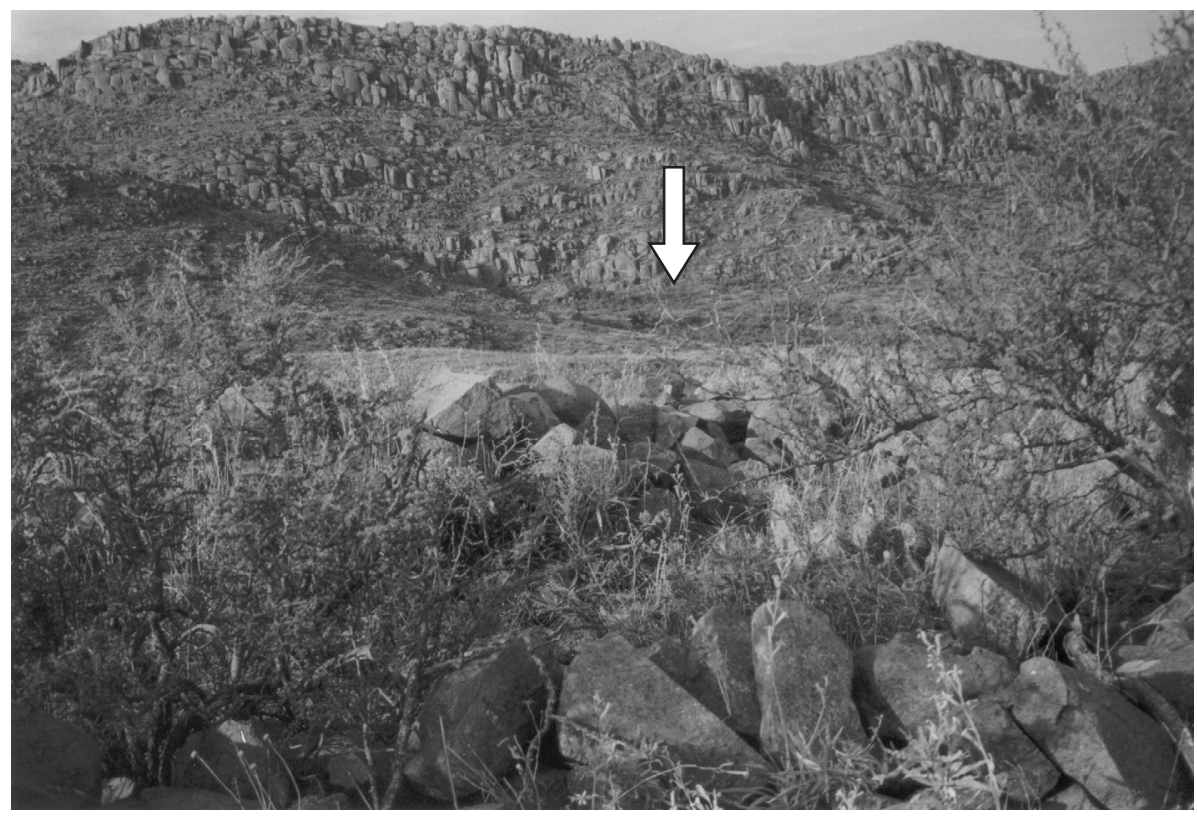

Figure 4: View of the structure two (E 2). At bottom the El Dolmen site (at the arrow's point).

Figura 4: Vista de la estructura dos (E2). Al fondo sitio El Dolmen (donde señala la flecha).

The stone structures E1 and E2 have yet to be excavated, but some examining shovel tests have been carried out as well as some movements of rocks; nevertheless without findings, thus making it difficult to assign a specific use. However, in the context of this social landscape it is possible to sustain that both structures functioned like symbolic markings. Namely, they could be considered as mnemonic signs; referential icons of the actors or of the social action involved and promoting agency on its own. Both structures are situated in the upper part of two high hills, located respectively at the face of the north and south valleys, which offers visibility to each from a distance. In similar manner, the topographical location of the rock paintings and its motives could be in relation to the significance of orientation and mobility of the landscape as well as with the exclusiveness and ownership of the environment. In this way, the significance of territoriality of the hunter-gatherer groups and the conformation of the territories delimited or 'marked' with different signs, the ideas of ownership, belonging (topophilia in Tuan 1977), and the use of the legitimized space through the worship/ ritual of the ancestors, constitute some aspects of the socialization process of the landscape through time (Morphy 1995, Parcero et al. 1998, Criado 1999). 


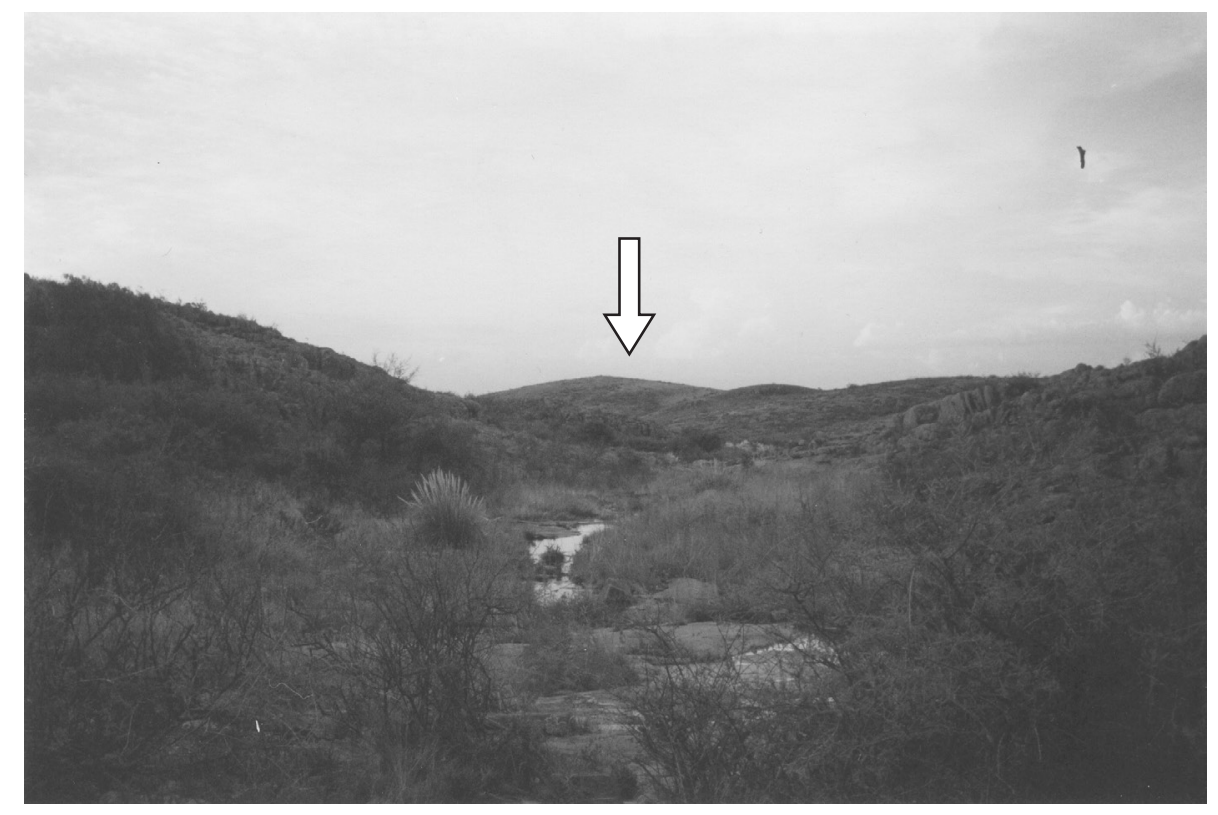

Figure 5: View, from the interior of Las Pinturas Valley, of the structure one (E 1) on the small hill at bottom (at the arrow's point).

Figura 5: Vista, desde el interior del Valle de Las Pinturas, de la estructura uno (E 1) sobre el cerro pequeño del fondo (donde señala la flecha).

\section{The socialization of the landscape}

In general, it can be proposed that the landscapes are social products, derived from the human action that is built and expressed in a temporal/spatial reference (Hirsch 1995). This idea implies that the places, space, and time are not pre-existent to the individuals but socially conceptualized and built. In this way, through their practices the social actors build their own places and landscapes (Tilley 1994). Thus the landscape is not something external waiting to be populated and equipped with meanings, but is internalized in the individuals and obtains its origin and expression through the social actions (Gosden 1994). The concept of landscape socialization implies the initiation of spatial patterning of activities in an environment built by humans. The reference system created by the structure of our actions forms not only the spaces in which to work but also forms the subjects spatially. Our bodies are spatially 'familiarized', adequate through the socialization process and conformed by standards for our relations to other people (Gosden 1994: 80). 
Accordingly, the socialization of the landscape through the cultural practices of 'monumentality' and/or 'objectiveness' can generate orderings and/or hierarchies of the space in "places" which are constituted in reference to the individuals and groups that approach them. In this context, a funeral structure where the dead are regularly deposited acquires singular relevance. Likewise, the structures or accumulations of stone (stone arrangements) located in the landscape to mark those special places, through time will play an important role in the activities to be developed. Among others things, their presence and maintenance reinforces the power and persistence of the sacred knowledge and of the place/landscape in which it is contained (Taçon 1994, Gianotti 2000, Madrid et al. 2000, Troncoso, 2004). These characteristics conjoin with the funeral structure, the rock paintings and the social arrangement of the landscape, can act as 'perceptual triggers' defining and prescribing places for visiting, acting, and moving within them (Tilley 1996).

\section{Final CONSIDERATIONS}

The practice of monumentalizing and the social relations expected and activated on space, together with different topographic items, can form part and be an expression of a landscape socialization process throughout time. This process, permanent in the making and in flux, can be manifested, objectified, and/or materialized through ideas, actions, constructing trails, paths and by the markings and arrangement of monuments in and on the surroundings. These physical elements, the actions and meanings can acts as mnemonic devices both, for the individuals and groups that carry out specific cultural practice, as well as for the future generations and for those that do not participate nor belong to that practice. Through the social action of marking the landscape there are long-range implications that surpass the synchrony of the event/action that gave it its origins. The monuments, as social and historical constructions, intrinsically possess a sense of permanence and durability. Thus the constructed landscape, socialized and loaded of meanings, is also "trans-generational" (Gosden 1994, Taçon et al. 1997). The rock paintings, human burials, and stone structures, all have a dimensional character that go beyond their materiality, on the one hand in and of itself they are icons that represent and signify something, and on the another hand they also obtain relevance in their composition and arrangement. That is to say, the monumentality is relevant by itself (as a monument), but also collectively as a combination by their association with 
people and by means of other characteristics of the landscape, be they other monuments, paintings or topographical features.

The visualization of the constructed landscape impels a perception of it associated and related to a differential space, with hierarchical places and with a power structure. In this sense, the visual perception of the constructions, colors, and dimensions of the architecture act in a mnemonic way triggering the social representation and a process of memory-work (Roe and Taki 1999). In the study area, the Lihué Calel hills constitute the most important component of the regional landscape. Not only do they contain the basic vital resources of subsistence in a semi-desert environment, but they also can be distinguished and visualized from a distance, creating a reference point in the surroundings. Such a landscape perception as this promotes the association of the landscape with someone, which is to say, it can manifest an identity between the places and its social actors. In general, these ideas can be extended to other places with continual or customary use such as extraction quarries of raw materials, springs, trails, rock painting sites, and that can be perceived as belonged and/or socially territorialized (Curtoni 1999, 2000; Bonomo 2006, Mazzanti 2006). Thus the process of landscape socialization can generate in the participating individuals a sense of belonging to it (Lovell 1998) and in those non participants a sense that the landscape is owned (Morphy 1995).

Thus, social identity can be originated and reproduced in reference to a specific location of the landscape and to a specific cultural context (Tilley 1994). This fact promotes a sense of attachment toward determined places that can be connected by the referential identification of human groups with certain territories. In Lihué Calel this seems to have occurred in relation to a ritual space configured in the landscape of the hills and expressed through the stone structures, the cemetery, and the rock paintings. The funeral structure or "chenque" is a place perceived as 'special', in western terms we would say 'sacred', which has been marked by other monuments and organized in a larger space, and has been repeatedly utilized to deposit the dead in a differential manner (see Berón et al. 2000, 2002). The continuous use of this socialized landscape is manifested in the funeral practices (always in the same place) in agreement with the elapse of time, in the construction of monuments/markings (possibly in a special territory), in the exclusiveness of the rock designs, and in the cultural incorporation/assimilation of physiographic features. In this temporary trajectory the places are created and recreated by the perception, experience, and the inhabitance of the landscape through a multiplicity of sensations and through naming 
and assigning values to them (Tilley 1994). The Lihué Calel hills, as a geomorphologic unit, surely constitutes a territory well delimited where the human groups established strong ties of ownership and roots with the place based on the worship of their ancestors. The sense of territoriality could have been expressed principally through the creation and consolidation of the ritual space, the temporality of its use, and the social identification of the constructed landscape.

Acknowledgments: We would also wish to thank Dan Rafuse for helping us with the final translation of the paper. Finally to the Dirección de Cultura de la provincia de La Pampa for their support with the researching, and to those who participate during the fieldworks.

Notes

1 There's a burial (Number 30) dated $1680 \pm 25$ (UGAMS 7437) that signals an earlier inhumation event, to be confirmed.

\section{BIBLIOGRAPHY}

Anschuetz, K., R. Wilshusen and C. Scheick 2001. "An Archaeology of Landscapes: Perspectives and Directions". Journal of Archaeological Research 9(2): 157-211.

Ashmore, W. and B. Knap. 1999. Archaeologies of Landscape. Contemporary Perspectives. Blackwell publishers, Massachusetts.

Barrientos, G., M. Leipus and F. Oliva. 1997. "Investigaciones arqueológicas en la Laguna Los Chilenos (provincia de Buenos Aires)". In Arqueología Pampeana en la década de los '90, edited by M. Berón and G. Politis, pp. 115-125. UNCPBA, Olavarría.

Barrientos, G. and I. Pérez. 2002. "La dinámica del poblamiento humano del Sudeste de la Región Pampeana durante el Holoceno". Intersecciones en Antropología 3: 41-54.

Bender, B, 1993. "Introduction". In Landscape politics and perspective, edited by B. Bender, pp: 1-17. Berg, Oxford.

Bender, B. 1998. Stonehenge. Making Space. Berg, Oxford. 
Bender, B., S. Hamilton and C. Tilley. 2007. Stone Worlds: Narrative and Reflexivity in Landscape Archaeology. Institute of Archaeology, University College, London, UK.

Berón, M. 1997. "Mobility and subsistence in a semidesert environment. The Curacó river basin (La Pampa, Argentina)". Quaternary of South America and Antarctic Peninsula 10: 133-166.

Berón M. 2004. Dinámica Poblacional y Estrategias de Subsistencia de Poblaciones Prehispánicas de la Cuenca Atuel-Salado- ChadileuvúCuracó, Provincia de la Pampa. Doctoral dissertation. Facultad de Filosofía y Letras, Universidad de Buenos Aires, Buenos Aires.

Berón, M. 2007a. "Integración de evidencias para evaluar dinámica y circulación de poblaciones en las fronteras del Río Colorado". In Arqueología de Fuego-Patagonia. Levantando piedras, desenterrando huesos...y develando arcanos, edited by F. Morello, M. Martinic, A. Prieto and G. Bahamonde, pp: 173-188. Ediciones CEQUA, Punta Arenas.

Berón, M. 2007b. "Circulación de bienes como indicador de interacción entre las poblaciones de la pampa occidental y sus vecinos". In Arqueología en las Pampas, edited by C. Bayón, A.Pupio, M.I. González, N. Flegenheimer and M. Frére, pp: 345-364. Sociedad Argentina de Antropología, Buenos Aires.

\section{Berón, M., I. Baffi, R. Molinari, G. Barrientos, C. Aranda and L.}

Luna. 2000. "Estructuras funerarias de momentos tardíos en PampaPatagonia. El chenque de Lihue Calel". In Desde el pais de los gigantes. Perspectivas arqueológicas en Patagonia Tomo 1: 141-160. Universidad Nacional de la Patagonia Austral, Río Gallegos.

Berón, M, E., Baffi, R., Molinari, C. Aranda, L. Luna and A. Cimino. 2002. "El Chenque de Lihué Calel. Una estructura funeraria en las Sierras de la Vida”. In Del mar a los salitrales. Arqueología pampeana en el umbral del tercer milenio edited by D. Mazzanti, M. Berón and F. Olvia, pp: 7-106. Universidad del Mar del Plata, Mar del Plata.

Berón, M. and R. Curtoni. 2002. Atlas Arqueológico de la Provincia de La Pampa. Serie Monográfica $N^{\circ}$ 2, INCUAPA. Facultad de Ciencias Sociales, UNCPBA. Olavarría. 
Berón, Mónica, C. Aranda and L. Luna. 2007. "Variabilidad y tendencias temporales de las prácticas mortuorias en el sitio Chenque I". Actas del XV Congreso Nacional de Arqueología Argentina, tomo III, pp: 247253. San Salvador de Jujuy, Argentina.

Bonomo, M. 2006. "Un acercamiento a la dimensión simbólica de la cultura material en la región pampeana". Relaciones de la Sociedad Argentina de Antropología XXXI: 89-115.

Borrero, L. 1989-90. "Evolución cultural divergente en la Patagonia Austral”. Anales del Instituto de la Patagonia 19: 133-140.

Bradley, R. 1991. "Ritual, time and history". World Archaeology 23(2): 209-219.

Bradley, R. 2002. An Archaeology of Natural Places. Routledge, London and New York.

Buikstra, J. and D. Charles. 1999. "Centering the ancestors: Cemeteries, mounds, and sacred landscapes of the ancient North American Midcontinent". In Archaeologies of Landscape, edited by W. Ashmore and A. Knapp pp: 202-228. Blackwell, Cambridge.

Cano, J. 1980. Inventario Integrado de los Recursos Naturales de la Provincia de La Pampa. Clima, Geomorfología, Suelo y Vegetación. Universidad Nacional de La Pampa, Santa Rosa.

Carmichael, D., J. Hubert, B. Reeves and A. Schanche. 1994. Sacred Sites, Sacred Places. Routledge, Londres.

Criado Boado, F. 1999. "Del terreno al Espacio: Planteamientos y Perspectivas para la Arqueología del Paisaje”. Capa 6: 1-82.

Curtoni, R. 1999. Archaeological approach to the perception of landscape and ethnicity in the West Pampean Region, Argentina. Master dissertation, Institute of Archaeology, University College London.

Curtoni, R. 2000. "La percepción del paisaje y la reproducción de la identidad social en la región pampeana occidental, Argentina". TAPA 19: $115-125$.

David, B. and J. Thomas. 2008. Handbook of Landscape Archaeology. Left Coast Press, Walnut Creek, CA. 
Gianotti, C. 2000. "Monumentalidad, ceremonialismo y continuidad ritual". TAPA 19: 87-102.

Gosden, C. 1989. "Prehistoric social landscapes of the Arawe Islands, West New Britain Province, Papua New Guinea”. Archaeology in Oceania 24: 45-58.

Gosden, C. 1994. Social Being and Time. Blackwell, London.

Gradín, C. 1975. Contribución a la Arqueología de La Pampa. Dirección provincial de cultura de la provincia de La Pampa, Buenos Aires.

Hernando, A. 1999. "The percepion of landscape among the Q'eqchi, a group of slash and burn farmers in the Alta Veracruz (Guatemala)". In The archaeology and anthropology of landscape, edited by P. Ucko and R. Layton, pp: 254-263. Routledge, Londres.

Hirsch, E. 1995. "Introduction". In The anthropology of landscape: Perspectives on place and space, edited by E. Hirsch and M. O'Hanlon, pp: 1-30.Clarendon Press, Oxford.

Hirsch, E y M. O'Hanlon. 1995. The anthropology of landscape. Perspectives on place and space. Clarendon Press, Oxford.

Hubert, J. 1994. "Sacred beliefs and beliefs of sacredness". In Sacred Sites, Sacred Places, edited by D.L. Carmichael, J. Hubert, B. Reeves and A. Schanche, pp: 9-19. Routledge, London.

Ingold, T. 1993. "The temporality of the landscape". World Archaeology 25 (2): 152-174.

Kirk, T. 1997. "Towards a phenomenology of building: the Neolithic long mound al La Commune-Seche, Colombiers sur Seulles, Normandy". In Semiotics of Landscape: Archaeology of mind, edited by G. Nash, pp: 59-70. BAR International Series 661. Oxford.

Küchler, S. 1993. "Landscape as memory: the mapping of process and its representation in a melanesian society". In Landscapes. Politics and perspectives, edited by B. Bender, pp. 85-106. Berg, Oxford.

Lovell, N. 1998. "Introduction. Belonging in need of emplacement?". In Locality and Belonging, edited by L. Lovell, pp: 1-24. Routledge, Londres. 
Luna, L., E. Baffi and M. Berón 2004. "El rol de las estructuras formales de entierro en el proceso de complejización de las poblaciones cazadorasrecolectoras del Holoceno tardío". In Aproximaciones contemporáneas a la Arqueología pampeana. Perspectivas teóricas, metodológicas, analiticas y casos de estudio, edited by G. Martínez, M. Gutiérrez, R. Curtoni, M. Berón and P. Madrid, pp. 61-73. Facultad de Ciencias Sociales, Olavarría.

Luna, L. 2008. Estructura Demográfica y Estilo de Vida de Cazadores Recolectores en un Ambiente de Desierto. Sitio Chenque I (Parque Nacional Lihué Calel, Provincia de La Pampa). Doctoral dissertation. Facultad de Filosofía y Letras, Universidad de Buenos Aires, Buenos Aires.

Madrid, P., G. Politis and D. Poiré 2000. "Pinturas rupestres y estructuras de piedra en las sierras de Curicó". Intersecciones en Antropología 1: 3553.

Mazzanti, D. 2006. "La constitución de territorios sociales durante el Holoceno tardío. El caso de las sierras de Tandilia, Argentina”. Relaciones de la Sociedad Argentina de Antropología XXXI: 277-300.

McGlade, J. 1995. "Archaeology and the ecodynamics of human-modified landscapes". Antiquity 69: 113-132.

Martínez, G., P. Bayala, G. Flensborg, and R. López. 2006. "Análisis preliminar de los entierros humanos del sitio Paso Alsina 1 (Pdo. de Patagones, Pcia. de Buenos Aires)". Intersecciones en Antropología 7: 97-108.

Martínez, G. and M. Figuerero Torres. 2000. "Sitio arqueológico La Petrona (partido de Villarino, provincia de Buenos Aires): Análisis de las modalidades de entierro en el área sur pampeana". Relaciones de la Sociedad Argentina de Antropologia XXV: 227-247.

Mitchell, T. 1994. Landscape and Power. The University of Chicago Press, Chicago and London.

Molinari, R. 1994. Lihué Calel: Antecedentes para el Plan de manejo de los recursos culturales. Administración de Parques Nacionales. Dirección de Conservación y Manejo. Departamento de Investigación. MS.

Morphy, H. 1995. "Landscape and the reproduction of the ancestral past". In The anthropology of landscape. Perspectives on place and space, edited 
by E. Hirsch and M. O'Hanlon, pp: 184-209. Clarendon Press, Oxford.

Muir, R. 1999. Approaches to Landscape. Macmillan Press Ltd., New York.

Nash G. y G. Children. 2008. The Archaeology of Semiotics and the Social Order of Things. BAR International Series 1833, Archaeopress, Oxford, UK.

Parcero, O., F. Criado and M. Santos. 1998. "Rewriting landscape: incorporating sacred landscapes into cultural traditions". World archaeology 30: 159-176.

Roberts, B.K. 1987. "Lanscape archaeology". In Landscape and culture: Geographical and archaeological perspectives, edited by J.M. Wagstaff, pp: 77-95. Blackwell, Oxford.

Roe, D, y J. Taki. 1999. "Living with stones: people and the landscape in Erromango, Vanuatu". In The archaeology and anthropology of landscape, edited by P. Ucko and R. Layton, pp: 411-422. Routledge, London.

Rossignol, J. y L. Wandsnider 1992. Space, Time and Archaeological Landscapes. Plenum Press, New York.

Schatzky, I. 1954. "Las pictografías de Lihué-Calel". Revista Geográfica Americana XXI: 220-221.

Shields, R, 1991. Places on the Margin. Alternative Geographies of Modernity. Routledge, London.

Stine, S. 1994. "Extreme and persistent drought in California and Patagonia during mediaeval time". Nature 369: 546-549.

Taçon, P, 1994. "Socialising landscapes: the long-term implications of signs, symbols and marks on the land". Archaeology of Oceania 29: 117-129.

Taçon, P, R, Fullagar, S, Ouzman and K, Mulvaney 1997. "Cupule engravings from Jinmium-Granilipi (northern Australia) and beyond: exploration of a widespread and enigmatic class of rock markings". Antiquity 71: 942-965. 
Thomas, J. 1993. "The politics of vision and the archaeologies of landscape". In Landscape politics and perspective, edited by B. Bender, pp: 19-48. Berg, Oxford.

Thomas, J. 2001. "Archaeologies of place and landscape". In Archaeological theory today, edited by I. Hodder, pp. 165-186. Polity Press, Oxford.

Tilley, C. 1994. A Phenomenology ofLandscape. Places, Paths and Monuments. Berg, Oxford.

Tilley, C. 1996. "The powers or rocks: topography and monument construction on Bodmin Moor". World Archaeology 28 (2): 161-176.

Troncoso, A. 2004. "El arte de la dominación: arte rupestre y paisaje durante el período Incaico en la cuenca Superior del Río Aconcagua". Chungara, Revista de Antropología Chilena 36(2): 453-461.

Tuan, Yi-Fu, 1977. Space and place. The Perspective of Experience. Edward Arnold, London.

Ucko, P. and R. Layton. 1999. The Archaeology and Anthropology of Landscape. Routledge, Londres.

Zetti, J. and R. Casamiquela. 1967. "Noticia sobre una breve expedición arqueológica a la zona de Lihue Calel”. Cuadernos del Sur : 5-40. 